\title{
剪断乱流の素過程に及ぼす界面活性剤の効果
}

\section{Influence of Surfactant on the Elementary Motions in Turbulent shear Flow}

$\begin{array}{llll}\bigcirc & \text { 大島 } & \text { 翼 (阪大院) } & \text { 正 } \quad \text { 太田貴士 (阪大工) } \\ \text { 正 } & \text { 梶島岳夫 (阪大工) }\end{array}$

Tsubasa OHSHIMA, Osaka University, 2-1 Yamadaoka, Suita, Osaka, Japan

Takashi OHTA, Osaka University, 2-1 Yamadaoka, Suita, Osaka, Japan

Takeo KAJISHIMA, Osaka University, 2-1 Yamadaoka, Suita, Osaka, Japan

Key Words: Drag reduction, Surfactant, Elementary Motion, Turbulent Shear Flow, Numerical Simulation

1 緒言 これまで, 高分子溶液や界面活性剂溶液による抵抗 低減流れの実験，またはそれらを模擬した数值訃算は数多く行 われている，それらによると，抵抗低減流れでは，低速ストリー クに対しては，壁面近傍でその間隔が大きくなり(1)，縦渦に対 しては渦度変動が減少する ${ }^{(1)}$ との報告がある。しかし，これら の研究ではいずれも流れ場が乱流状態であり, 乱流構造の要素 間の相互作用が強いため，界面活性剤による抵抗低減の機構が どこに作用したのかを判断することが困難である、そこで，本 研究では，単独の低速ストリーク，および一対の縦渦を層流中 に発生させて数值訃算を行い, 乱流摩擦抵抗低減流れの素過程 として，界面活性剤が縦渦や低速ストリークにどのような影響 を与えるかを調べることが目的である.

2 数値計算法 計算領域は主流方向から見て, 上下左右が壁 に囲まれた正方形断面の 3 次元ダクトである。流入境界条件に はダクト内において十分に発達した層流の解析解を与え続け, 壁面には滑りなし条件，流出境界条件には対流流出条件を用い た．流れが層流になるように，ダクトの一辺，ダクト内の平均 流速基準のレイノルズ数を層流の条件である 1000 に設定した. 基礎式は連続の式, Cauthy の運動方程式, 応力構成方程式は, 垂直応力項はニュートン粘性とし, せん断応力項のみに非ニュー トン性を考慮する。粘度式には, 以下の Bird-Carreu モデル

$$
\eta(\dot{\gamma})=\eta_{0}\{1+(t \dot{\gamma})\}^{\frac{n-1}{2}}+\eta_{\infty}
$$

を用いた，あるせん断速度領域において，粘度が急上昇する SIS 状態を表現するため，Usui ら ${ }^{(2)}$ が測定した Bird-Carreau モ デルの定数を, SIS 状態を含む場合と含まない場合を定義して おき, 流れ場の中で縦渦や低速ストリークなどせん断速度の大 きい領域だけ，局所的に高粘度になるように調整した。縦渦の 発生方法は, 一対の縦渦を流入条件として用い, 低速ストリー クについては, 主流と逆方向に, 速度に応じた抵抗力を与える ことで表現している.

3 計算結果と考察 図 1,2 に低速ストリークを発生させた計 算の, ニュートン流体と非ニュートン流体の主流方向に垂直な 断面に拈ける低速領域の等高線 $\left(u^{\prime} / U_{m} \leq-1.5\right)$ と，その断 面における瞬時の速度ベクトルを示す。断面はストリーク発生 直後の $x=1.2$ と下流の $x=3$ を選んでいる。速度べクトルを 見ると, ニュートン流体の場合の図 1(a)では, ストリークの付 近で渦が発生していることが分かる．図 1(b) では，瀜は図 1(a) に比べて減衰しているが, 存在し続けている様子が観察される. 非ニュートン流体の場合の図 $2(\mathrm{a})$ でも, ストリークの付近に渦

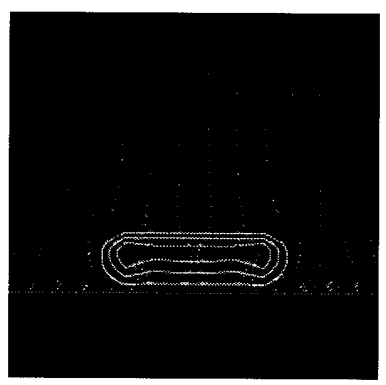

(a) $x=1.2$

Fig. 1: Low-speed region and instantaneous velosity vector of streamwise cross-section in Newtonian fluid flow, $\left(u^{\prime} / U_{m} \leq-1.5\right)$

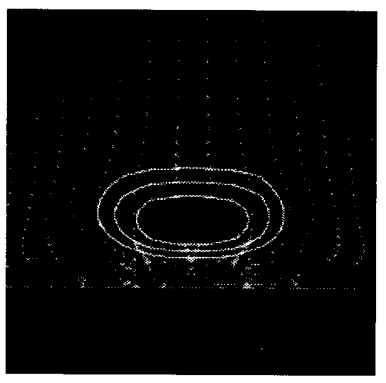

(a) $x=1.2$



(b) $x=3$
Fig. 2: Low-speed region and instantaneous velosity vector of streamwise cross-section in Non-Newtonian fluid flow, $\left(u^{\prime} / U_{m}\right.$ $\leq-1.5)$

が存在する。しかし，下流の図 2(b) では渦は見られない.

ニュートン流体の場合, 縦渦と低速ストリークには関係があ ると考えられるが, 非ニュートン流体の場合，下流では縦渦と 低速ストリークの関係が小さくなっている。このように，ニュー トン流体と非ニュートン流体の場合では，ストリークの維持機 構が異なり, 乱流要素の構造も変化すると考えられる。

参考文献

(1) C.D.Dimitropoulos, J.Non-Newtonian Fluid Mech, 79(1998), 433-468.

(2) H.Usui, Rheol.Acta, 37(1998), 122-128. 